\title{
Transnational Families Between Africa and Europe
}

\author{
Valentina Mazzucato \\ Maastricht University \\ Djamila Schans \\ Research and Documentation Centre (WODC), Ministry of Justice \\ Kim Caarls \\ Maastricht University \\ Cris Beauchemin \\ Institut National d'Études Démographiques (INED)
}

This paper provides a descriptive and comparative analysis of transnational families with members located in Africa and Europe. It is thus far the only quantitative study, to our knowledge, that includes crosscountry comparisons and focuses on the African European context. By comparing both countries of origin and destination, differences in family arrangements are found among Ghana, Senegal, and the Democratic Republic of Congo as well as within these groups depending on the European destination countries. Findings show that dates of arrival and migrant legal status are most commonly associated with transnational family forms. Family and gender norms at origin, migration motivations, destination country family reunification and migration policies, and destination country characteristics related to language, employment opportunities, and educational system help to explain the differences found.

\section{INTRODUCTION}

Methodologically and theoretically, migrant families have been predominantly conceived of as nuclear, living together, and bounded by the nation-state, until the transnational turn in migration studies at the 
beginning of the 21 st century. Families, and migrant families in particular, unlike the household, are not necessarily defined by co-residence or spatial proximity (Bernhard, Landolt, and Goldring, 2009; Glick, 2010). Family relationships can exist across long distances and in multiple locations for indeterminate periods of time. The boundaries of the family are based on relationship structures and activity flows, not on geographic location (Fox and Luxton, 2001; Herrera-Lima, 2001).

The academic literature on transnationalism (Basch, Glick-Schiller, and Szanton-Blanc, 1994; Faist, 2000; Wimmer and Glick-Schiller, 2002) has highlighted the fact that currently, through the ease of traveling long distances by plane, the proliferation of money transfer technologies and institutions, and advances made in information and communication technologies, migrants often maintain a variety of ties with countries of origin through regular visits, transactions such as remittances, and communications via computers and cellular telephones. Thus, while transnational linkages have characterized migrants' relationships with home throughout the centuries, the frequency and simultaneous nature of contact today leads to qualitative differences in the relationships migrants maintain (Foner, 1997). In this paper, we focus on transnational family relationships. Transnational families are "families that live some or most of the time separated from each other, yet hold together and create something that can be seen as a feeling of collective welfare and unity, namely 'familyhood', even across national borders" (Bryceson and Vuorela, 2002:3). The flows of goods and money sent by migrants to their families back home make transnational families key actors in the "counter circuits of globalization" (Sassen, 2002). Yet transnational family connections go beyond material exchange. Several studies on transnational families highlight the fact that inter-generational care is being arranged and negotiated from a distance and that family obligation and reciprocal relationships continue after migration (Schmalzbauer, 2004; Mazzucato and Schans, 2011).

Until recently, relatively limited attention was paid to family dynamics in transnational migration studies (König and de Regt, 2010). Much of this recent literature has focused on the problems experienced by families living transnationally (Parreñas, 2004; Schmalzbauer, 2004; Pribilsky, 2007). The focus has been on the emotional difficulties of parents who are separated from their children (Hondagneu-Sotelo and Avila, 1997; Parreñas, 2004; Schmalzbauer, 2004; Bernhard, Landolt, and Goldring, 2005; Dreby, 2006), the tensions in spousal long-distance relationships 
(Manuh, 1999; Pribilsky, 2007), and feelings of resentment and abandonment experienced by children at home (Suarez-Orozco, Todorova, and Louie, 2002; Parreñas, 2004; Dreby, 2007). These studies focus on effects of transnational family life and the lived experiences of migrants and their families back home. This study seeks to complement these micro-level studies by focusing on the prevalence and associated characteristics of transnational families. The cross-country comparative approach allows us to explore some macro-level factors that shape the associations we find.

What little we know about transnational family arrangements derives from studies focusing on Latin American flows to North America or South-East Asian cases, and increasingly on Chinese internal migration. A gap remains in knowledge on African cases (although see Riccio, 2008; Coe, 2011; Ảkesson, Carling, and Drotbohm, 2012; Haagsman and Mazzucato, 2014). Filling this gap is important because African migration represents an increasingly significant flow of "new" migration to Europe (Koser, 2003; Grillo and Mazzucato, 2008) and also because African family systems have been characterized in anthropological studies as being particularly flexible, with familial responsibilities and roles distributed among extended family members (Goody, 1982; Bledsoe, 1990). As such, African families may show different tendencies than transnational families originating from other parts of the world. Recent socio-anthropological studies indicate that living transnationally can be a rational and even functional strategy in many African contexts (Riccio, 2008; Bledsoe and Sow, 2011) instead of an imposed state of being while awaiting reunification. At the same time, comparing different cases of African migratory flows is useful as family structures and functioning vary across African countries, so that the way families manage migration may be heterogeneous.

Studying the European context is important as it presents legal and political conditions that are quite different from the U.S. and Asian contexts. Furthermore, European countries present different "contexts of reception" (Portes and Rumbaut, 1990) in terms of laws affecting migrant family life, making it important to consider the effect of various European contexts in shaping transnational family life (Pascouau and Labayle, 2011). Family-related migration has become the major source of new immigration to most Western European migrant-receiving countries and restrictions on family reunification multiply (King et al., 2010). This means that besides the individual motivations of migrants and the wishes of the family "left behind," state policies more and more influence decisions on reunification. 
While qualitative studies on the effects of transnational family life have multiplied over the past decade, the exact prevalence of transnational family arrangements worldwide is unknown due to a scarcity of quantitative evidence. Nevertheless, some initial reports indicate that the existence of transnational families is a substantial phenomenon, justifying further research. For example, international organizations such as Save the Children and UNICEF report that approximately 25 percent of children in selected migrant-sending countries have at least one parent abroad (Mazzucato and Schans, 2011). In China, studies report that approximately 58 million children and 47 million wives live in families that have been separated due to migration (Wen and Lin, 2012). ${ }^{1}$

This paper presents quantitative findings regarding the prevalence of transnational migrant families living between sub-Saharan Africa and Europe and the factors that characterize transnational families. We define a transnational family as a nuclear family - typically a couple with a child or children under the age of 18 , but also couples without children, or one parent with his or her minor child or children - where at least one of the adult members lives in another country for more than 1 year. While we limit our analyses to nuclear family members, we embed our findings within knowledge of family norms that include extended family, social parenthood and child fostering, and spousal multilocal residence. Our findings therefore have bearing to first-generation migrants and their nuclear family members. The study uses a unique dataset collected under the Migration between Africa and Europe (MAFE) project, containing information on both migrant-sending countries (Senegal, the Democratic Republic of Congo [DR Congo], and Ghana) and migrant-receiving countries (Belgium, the Netherlands, the UK, France, Italy, and Spain), thus providing a multisited representation of migrant family life. The paper is structured as follows: In the first section, we describe the background situation for families living in both Africa and Europe, discussing family structures in sub-Saharan Africa and the policy context regarding migration and family reunification in Europe. Next, we describe the data used for this study. We then provide descriptive insights regarding the prevalence and forms of transnational migrant families and apply logistic regression techniques to assess which factors are associated with membership in a transnational family. In the discussion and conclusions

\footnotetext{
${ }^{1}$ This relates to internal, rural-to-urban migration but, given the great distances within China, it can be comparable to international migration in terms of family separation.
} 
section, we reflect on the findings and provide suggestions for future research.

\section{BACKGROUND}

\section{Family Structure in Sub-Saharan Africa}

Families in many parts of Africa have been described as fluid and based on an extended family system. This fluidity is related in part to the long history of internal and international migration in this part of the world. The migration of household members is a common strategy for family survival and increasing income-earning opportunities. Children may be relocated to other households within the extended family to facilitate migration, among other reasons (Tiemoko, 2003; Øien, 2006). Over the past decades, migration patterns have shifted from migration within Africa toward migration to an increasing number of countries in Europe and North America (Grillo and Mazzucato, 2008). This type of international migration has consequences for the organization of family life, although these consequences are not well understood.

Locoh (1989) identified some key characteristics of African family life, including the tendency toward extended family structures, sharp separation of gender responsibilities, lineage solidarity that is stronger than conjugal solidarity, integration of reproductive and productive functions, and the dominance of elders. Despite these generalizations, the organization of family life and patterns of migration differ among the African countries. For example, polygamous marriage is more common in Senegal than in Ghana and the DR Congo. Additionally, whereas independent migration of women to Europe from the DR Congo and Ghana is common, the stricter gender hierarchy in certain regions of Senegal gives women less freedom to move independently (for details, refer to Bruggenhagen, 2004; Beauchemin, Caarls, and Mazzucato, 2013; Caarls et al., 2013; Schoumaker and Flahaux, 2013).

In the African countries in focus in this article, a rather high proportion of spouses live apart together, irrespective of migration, that is, spouses live in different residencies in the same town or in different areas of the same country or in different countries. In these countries, partner choice is not predominantly a personal matter: Matrimonial unions are often alliances between families rather than individual companionships, and such decisions are made and/or approved by the elders of the lineage. 
Particularly in Senegal, marriages entail low levels of conjugal interaction (Findley, 1997:120-3). In daily life, husbands and wives eat their meals separately, rarely socialize, and have separate rooms, if not separate houses, as is often the case in Dakar among polygamous families (Marie, 1997). Women in Ghana, especially in matrilineal systems prevalent among the Akan in Southern Ghana where many migrants come from, are said to be independent, managing their own economic activities and keeping separate budgets from their husbands. Furthermore, family support for a married woman upon dissolution of her marriage is greater in matrilineal than in patrilineal systems. The strength of this family support from the matrikin has been identified as a primary factor to the high incidence of divorce among the Akan (Fortes, 1950). Multiresidence among couples is common in DR Congo as well, although this has been mainly described for rural households. While extended families continue to be important, processes of urbanization tend to reinforce nuclear families and co-residence in all three countries (Ngondo, 1996; Clark, 1999).

Living apart is common not only for couples but also for children, where child fosterage is practiced. Circulation of children is part of the social system in a context in which direct biological links are not necessarily considered to be the most important bonds. In Senegal, the proportion of fostered children under the age of 15 is the highest in West Africa, with 28 percent of all children being fostered in rural areas and 35 percent in urban areas (Locoh and Mouvagha-Sow, 2005:14). In Ghana, the national figure for child fostering is 15.6 percent of the total population of children under 15 (Ghana Statistical Service, Ghana Health Service, and ICF Macro, 2009), and in the DR Congo, the proportion is 19.3 percent (Ministère du Plan et Macro International, 2008). These figures show the normative nature of children not being raised by their biological parents in the countries surveyed. However, the figures include fostering irrespective of whether parents have migrated. Furthermore, they do not include cases in which one parent has migrated and the child lives with the other parent.

\section{The Receiving Context in Europe}

Decisions on how to organize family life across borders are influenced not only by the family systems practiced in the country of origin but also by the migrant-receiving context, most notably visa/citizenship and family reunification policies. Family-related migration has become one of the 
main entry gates for non-EU migrants into the European Union, and as a consequence, family-related modes of entry have come increasingly under the scrutiny of European governments as a means of restricting migration (Kraler, 2010). Family migration policies define which family members are eligible for family-related admission and under which conditions. Aspects such as who is and who is not part of the family and who holds responsibility over whom need to be repeatedly proven by migrants and their families.

European countries differ in their policies and laws regarding family migration. While in the Netherlands and France, family reunification has been highly debated and contested, family migration was marginal to the public debates on migration policy in Italy and Spain. Currently, the proportion of third-country nationals admitted for family reasons is around 47 percent of all in-migration in the Netherlands and 60 percent in France. In Italy and Spain, the recorded share of family-related migration is lower, reflecting the high proportion of irregular migrants who might be de facto reunified but do not have legal status (Kraler, 2010; Gonzalez Ferrer, 2011). In the UK, family migration policies were very restrictive during the 1980s and 1990s (Bhabha and Shutter, 1995), but were temporarily liberalized in the late 1990s (Kofman et al., 2008). More recently, the UK has become stricter again. Debates on family migration currently focus on abuses of the system, particularly through "scam marriages," and policies have been implemented to impede such marriages, such as the Immigration and Asylum Act of 1999. In countries such as the Netherlands and the UK, a pre-entry test has been instituted for family migrants in recent years (Kraler, 2013).

Family reunification and formation has become increasingly difficult and dependent on factors such as class, ethnicity, nationality, and gender (Kraler, 2010). Undocumented migrants, for example, have no legal means for family reunification. France and Belgium have specific provisions restricting reunification with children from polygamous relationships, and reunification with another spouse from such a relationship is ruled out explicitly (Pascouau and Labayle, 2011). Additionally, in France, all members of the nuclear family (spouse and children under 18 years of age) have to be reunified at the same time.

In all countries, additional requirements are attached to the right of family reunification, including minimum income requirements, the requirement that spouses/partners need to physically join the sponsor in his/her place of residence, and active family ties (i.e., not having been 
separated for too long). These conditions, as well as the restrictions placed on family-related migrants, not only constrain and define the choices and opportunities available for individuals and their families but also represent particular and Western understandings of the family as a social institution and how it should be structured internally (Kraler, 2010:47). Furthermore, these restrictions result in gendered and class outcomes as income requirements are difficult especially for women occupying working class jobs (Van Walsum, 2009). Because restrictions and conditions differ between countries in Europe (with the Netherlands, France, and the UK having stricter conditions than Belgium, Italy, and Spain; <www. mipex.eu $>$ ) and because, even within countries, restrictions and conditions vary for different migrants, we expect to see differences in the prevalence of transnational family arrangements depending on the receiving country.

\section{DATA AND METHODS}

This paper aims to provide a comprehensive picture of the organization of family life within specific migratory flows between Africa and Europe, using data collected from the MAFE project (Beauchemin, 2012). The MAFE dataset includes information from both African migrant-sending countries and European migrant-receiving countries. This paper uses the biographic retrospective surveys conducted in the European receiving countries. The information is multisited in that it contains data on nuclear family members, including those located in another country.

The selection of cases sought to reflect some of the diversity that can be found both on the African and on the European continents. DR Congo, Ghana, and Senegal offer contrasting case studies in several ways. They have different contemporary historical backgrounds, different colonial histories and paths to independence, and diverse recent political and economic contexts. DR Congo has experienced great political and economic instability since the early 1980s, while Senegal and Ghana represent cases of relative stability and economic progress in a context of repeated political change. Senegal, with respect to the other two countries, has a proportionately larger Muslim population and a stronger patriarchal system guiding family norms. The selection of European destination countries reflects former colonial relationships (Congo-Belgium; GhanaUK; Senegal-France) but also includes one or two additional "new" destinations (Congo-UK; Ghana-the Netherlands; Senegal-Italy and Spain) for comparative purposes. The reason for this selection is that the 
expanded migration from Africa to Europe that began in the 1980s tended to follow the old colonial ties between countries; however, since the 1980s, these flows have been diversifying to include new destinations such that Senegalese migrants are now found in large numbers in Italy and Spain, Congolese in the UK, and Ghanaians in the Netherlands (Grillo and Mazzucato, 2008; Schoumaker and Flahaux, 2013). A crosscountry comparative approach can help us to understand how different contextual factors in origin and destination countries shape the way in which migrant socioeconomic and migration characteristics are linked to transnational family formations.

The data collection for the migration flows from all three sending countries took place between 2008 and 2009. The biographic surveys were collected in urban areas in the European receiving countries (Belgium, France, Italy, Spain, the UK, and the Netherlands) and in rural areas in Italy and Spain, given the dispersed nature of migrant settlement patterns in these two countries. The surveys collect retrospective life histories, focusing on topics related to family formation, education, employment, housing, migration, and investments. Respondents were eligible if they were between 25 and 75 years of age, were born in Ghana, Senegal, or the DR Congo, had at any point in their lives the citizenship of one of these countries, and had lived away from their country of origin for at least one consecutive year.

In the European countries, no suitable sampling frame was available due to the large number of undocumented migrants, with the exception of Spain (where the Padrón registration system provides a reliable baseline); therefore, quota sampling was used. In all countries, migrants were selected in the areas where the majority of migrants reside, and quotas were set by age and gender. In France, the socio-professional category was also included as a quota criterion, and in Belgium and the UK, the place of residence was additionally used. To ensure variety in types of respondents, different recruitment methods and types of recruiters were employed. In total, 1,456 African migrants were surveyed in Europe. Table 1 presents the three samples for each migration flow.

The data used in this article pertain to nuclear family members, that is, spouse and children under the age of 18. While, as explained above, African family norms are flexible and inclusive, we use this more restrictive definition because only nuclear family members qualify for reunification under the European countries' migration laws. A transnational family is defined as a family in which a migrant's spouse and/or at least one 
TABLE 1

Overview of the Migration Between Africa and Europe (MAfE) Samples

\begin{tabular}{|c|c|c|c|c|c|c|}
\hline \multirow[b]{2}{*}{ Survey country } & \multicolumn{2}{|c|}{ Ghanaian flow } & \multicolumn{2}{|c|}{ Congolese flow } & \multicolumn{2}{|c|}{ Senegalese flow } \\
\hline & $f$ & $\%$ & $f$ & $\%$ & $f$ & $\%$ \\
\hline the Netherlands & 273 & 64.7 & & & & \\
\hline UK & 149 & 35.3 & 149 & 34.8 & & \\
\hline Belgium & & & 279 & 65.2 & & \\
\hline France & & & & & 201 & 33.2 \\
\hline Spain & & & & & 200 & 33.0 \\
\hline Italy & & & & & 205 & 33.8 \\
\hline Total & 422 & 100 & 428 & 100 & 606 & 100 \\
\hline
\end{tabular}

Note: Unweighted frequencies and weighted percentages are shown.

Source: MAFE-Ghana; MAFE-Congo; MAFE-Senegal - Biographic surveys.

child under the age of 18 is living in another country, be it the home country or another country. This definition implies that, in some cases, a migrant may be living with part of his or her nuclear family, such as when some children are with the migrant and some are in the country of origin, while in other cases, the migrant may be separated from all nuclear family members. Migrants without a nuclear family - not having a spouse and/or child(ren) - are only included in the descriptive analysis. For migrants who were in a polygamous marriage - which mainly occurred in the Senegalese sample - the classification into the "transnational family" category is based on the location of one (the most recent) spouse. This choice was made for the sake of comparative analysis, yet analyses in which all polygamous spouses were included (not shown) reveal similar results.

In the first part of the analysis, descriptive insights are provided regarding the prevalence and forms of transnational migrant families, concentrating on current migrants living in the six European countries under study. Second, logistic regressions are used to assess which factors are associated with the probability of being in a transnational family at the time of the survey. Separate estimations are made for the pooled sample, which merges all European destination countries for each migration flow, and for each European country separately. For each of the samples, two models are included to show the stepwise estimation: first a model with the sociodemographic characteristics and then a model that adds migration-related characteristics as well as country dummies for the pooled sample. Sampling weights are used when reporting percentages but not frequencies (see Schoumaker and Mezger, 2013, for weight computations). For the logistic regression, no sampling weights were used. 


\section{Measures of Variables for the Logistic Regressions}

The dependent variable is a dichotomous variable indicating whether a migrant is in a transnational family or lives together with all members of his or her nuclear family, at the time of the survey. We control for the sociodemographic characteristics of respondents found to be most important in the studies reviewed above: age (in single years); gender (with 0 for male and 1 for female); education (years of schooling); occupational status (ISEI score ${ }^{2}$ ); and subjective wealth status (in answer to the question: "All in all, would you say that during this period you had enough to live on from day to day?" with response categories: "absolutely," "it depended," and "not at all"). Second, migration-specific characteristics were included: period of arrival at current destination (in single years) and residency status (with three options: a residence permit/citizenship, a visa, and no residence permit/citizenship, i.e., undocumented). Due to multicollinearity between period of arrival at current destination, duration of stay, and age at arrival, the latter two variables were not included. Finally, for the pooled samples, dummy variables were included for the country of survey. Table 2 presents an overview of the variables.

\section{FINDINGS}

Different family arrangements can emerge from international migration. Families can end up living transnationally, on different sides of nationstate borders, such as when a mother migrates while her husband and children stay in the country of origin or when a husband migrates and leaves a pregnant wife who gives birth in the country of origin. Family members can also live all together, when they migrate all at the same time or when they reunify after a period of living separately, or when families are formed at destination, such as when a wife and husband migrate together and give birth to children in the destination country or when partners marry overseas and start a family there. However, little is known about these arrangements, including their prevalence or the characteristics of people in such families. This section presents the findings on migrant family arrangements, first describing the prevalence of different family

\footnotetext{
${ }^{2}$ ISEI stands for the International Socio-Economic Index of Occupational Status, which is a continuous indicator of occupational status, with index scores derived from education and income and with higher scores representing higher occupational statuses.
} 
TABLE 2

Overview of the Variables Used for Logistic Regression, by Migration Flow

\begin{tabular}{|c|c|c|c|c|c|c|c|c|c|}
\hline \multirow[b]{2}{*}{ Variables } & \multicolumn{3}{|c|}{ Ghana } & \multicolumn{3}{|c|}{ Congo } & \multicolumn{3}{|c|}{ Senegal } \\
\hline & $f$ & $\% / M(\mathrm{SD})^{\mathrm{a}}$ & Range & $f$ & $\% / M(\mathrm{SD})$ & Range & $f$ & $\% / M(\mathrm{SD})$ & Range \\
\hline \multicolumn{10}{|l|}{ Transnational family } \\
\hline No & 188 & 65.1 & & 208 & 33.3 & & 229 & 48.1 & \\
\hline \multicolumn{10}{|l|}{ Gender } \\
\hline Female & 143 & 49.5 & & 138 & 44.2 & & 218 & 45.8 & \\
\hline Male & 146 & 50.5 & & 174 & 55.8 & & 258 & 54.2 & \\
\hline Age & 289 & $43.1(9.5)$ & $23-65$ & 312 & $42.9(9.6)$ & $25-74$ & 476 & $42(8.4)$ & $26-71$ \\
\hline Education & 288 & $16.1(3.7)$ & $0-23$ & 311 & $17.1(3.9)$ & $0-27$ & 473 & $8.9(5.7)$ & $0-20$ \\
\hline Occupational status & 230 & $36.7(16.6)$ & $16-76$ & 168 & $41.6(17.2)$ & $16-89$ & 445 & $30.1(12.5)$ & $10-76$ \\
\hline \multicolumn{10}{|c|}{ Subjective wealth status } \\
\hline Absolutely & 208 & 73 & & 238 & 77.3 & & 333 & 71 & \\
\hline It depended & 55 & 19.3 & & 59 & 19.2 & & 113 & 24.1 & \\
\hline Not at all & 22 & 7.7 & & 11 & 3.6 & & 23 & 4.9 & \\
\hline Period of arrival & 288 & $1997(8.7)$ & $1965-2008$ & 309 & $1998(7.4)$ & 1963-2008 & 476 & $1996(7.8)$ & $1967-2008$ \\
\hline \multicolumn{10}{|c|}{ Residence permit $(\mathrm{RP})^{\mathrm{b}}$} \\
\hline Visa & 36 & 12.7 & & 33 & 10.8 & & 29 & 6.2 & \\
\hline No RP & 31 & 10.9 & & 23 & 7.5 & & 47 & 10 & \\
\hline \multicolumn{10}{|l|}{ Survey country } \\
\hline UK & 100 & 34.6 & & 114 & 36.5 & & & & \\
\hline the Netherlands & 189 & 65.4 & & & & & & & \\
\hline Belgium & & & & 198 & 63.5 & & & & \\
\hline France & & & & & & & 146 & 30.7 & \\
\hline Spain & & & & & & & 167 & 35.1 & \\
\hline Italy & & & & & & & 163 & 34.2 & \\
\hline
\end{tabular}

Notes: Unweighted frequencies and weighted percentages are shown.

Migrants without a nuclear family are excluded for the logistic regressions and therefore also for this Table.

${ }^{a}$ Percentages are reported for categorical variables; means and standard deviations are reported for continuous variables (i.e., age, education, occupational status, and period of arrival).

${ }^{\mathrm{b}}$ Residence permit: $\mathrm{RP}=$ migrant has a residence permit or does not require one due to citizenship acquisition; Visa $=$ migrant has a visa; No RP $=$ migrant does not have a permit (i.e., undocumented migrant). Source: MAFE-Ghana; MAFE-Congo; MAFE-Senegal - Biographic surveys. 
arrangements among the studied samples. The family arrangements are presented separately for spouses and for children, as well as jointly to show the prevalence of transnational family life in general. Second, this section investigates what characteristics are associated with transnational families compared to families who live together. In the section that follows this one, these findings will be discussed.

\section{Migrant Families in Europe}

Table 3 presents an overview of the composition of the samples as well as differences between receiving countries for each migration flow.

Some important differences exist among the three African migration flows and among the various receiving countries, showing the relevance of considering multiple sending and receiving contexts. First, looking at the differences among the three flows, the Senegalese sample consisted of more men, reflecting the fact that Senegalese migration flows have historically been and are still male-dominated (Beauchemin, Caarls, and Mazzucato, 2013). In terms of age, Ghanaian migrants are, on average, older than Congolese and Senegalese migrants. More Ghanaian and Congolese migrants have acquired a tertiary education (65\% and 52\%, respectively), iile only a small proportion of the Senegalese migrants have done so $(18 \%)$.

Turning to the differences among receiving countries for each of the three flows, Ghanaian migrants in the UK have, on average, acquired higher education than Ghanaian migrants in the Netherlands. Congolese migrants in Belgium are slightly older than those in the UK, reflecting the longer history of Congolese migration to Belgium. Opposite to the Ghanaian flow, Congolese migrants in the UK have lower levels of education than those in Belgium. There are more Senegalese women in France, and in general, Senegalese migrants in France are significantly older than those in Spain and Italy and are more highly educated. Finally, undocumented migrants (i.e., those not having a residence permit or a visa) are more common in the Netherlands than in the UK for Ghanaian migrants, in the UK than in Belgium for Congolese migrants, and in Spain and Italy than in France for Senegalese migrants.

A general pattern emerges in which migrants moving to a country with former colonial ties, tend to be slightly older (in France and in Belgium), and are less likely to be undocumented, reflecting the longer migration history between these countries and the longer time migrants 
TABLE 3

Overview of the Key Demographic Characteristics of African Migrants in Europe

\begin{tabular}{|c|c|c|c|c|}
\hline \multirow[b]{2}{*}{ Variables } & \multicolumn{4}{|c|}{ Ghanaian flow } \\
\hline & $\begin{array}{c}\text { Full sample }(n=410) \\
\% / M(\mathrm{SD})^{\mathrm{a}}\end{array}$ & $\begin{array}{l}\text { The Netherlands } \\
(n=263) \\
\% / M(\mathrm{SD})\end{array}$ & $\begin{array}{c}\text { The UK }(n=147) \\
\% / M(\mathrm{SD})\end{array}$ & Significance \\
\hline Sex (\% men) & $53 \%$ & $49 \%$ & $54 \%$ & - \\
\hline Age & $42.1(0.8)$ & $42.9(0.6)$ & $42.0(0.9)$ & - \\
\hline \multicolumn{5}{|l|}{ Education } \\
\hline Primary $(<)$ & $27 \%$ & $19 \%$ & $28 \%$ & * \\
\hline Secondary & $8 \%$ & $46 \%$ & $3 \%$ & $* * *$ \\
\hline Tertiary & $65 \%$ & $35 \%$ & $69 \%$ & $* * *$ \\
\hline \multicolumn{5}{|c|}{ Residence permit ${ }^{\mathrm{b}}$} \\
\hline $\mathrm{RP}$ & $68 \%$ & $74 \%$ & $67 \%$ & - \\
\hline Visa & $24 \%$ & $8 \%$ & $27 \%$ & $* * *$ \\
\hline No RP & $8 \%$ & $18 \%$ & $6 \%$ & $* * *$ \\
\hline
\end{tabular}

Congolese flow

\begin{tabular}{lcccc}
\cline { 2 - 5 } Variables & $\begin{array}{c}\text { Full sample }(n=426) \\
\% / M(\mathrm{SD})\end{array}$ & $\begin{array}{c}\text { Belgium }(n=278) \\
\% / M(\mathrm{SD})\end{array}$ & $\begin{array}{c}\text { The UK }(n=148) \\
\% / M(\mathrm{SD})\end{array}$ & Significance \\
\hline Sex $(\%$ men $)$ & $45 \%$ & $44 \%$ & $45 \%$ & - \\
Age & $40.5(0.5)$ & $41.4(0.6)$ & $39.3(0.8)$ & $*$ \\
Education & & & & $*$ \\
$\quad$ Primary $(<)$ & $17 \%$ & $90 \%$ & $27 \%$ & $* *$ \\
$\quad$ Secondary & $31 \%$ & $61 \%$ & $42 \%$ & - \\
$\quad$ Tertiary & $52 \%$ & $70 \%$ & $41 \%$ & $*$ \\
Residence permit & & $21 \%$ & $85 \%$ & $* * *$ \\
$\quad$ RP & $76 \%$ & $9 \%$ & $2 \%$ & $* * *$ \\
$\quad$ Visa & $13 \%$ & & $14 \%$ & - \\
No RP & $11 \%$ & & & $*$ \\
\hline
\end{tabular}

Senegalese flow

\begin{tabular}{|c|c|c|c|c|c|}
\hline Variables & $\begin{array}{l}\text { Full sample } \\
(n=603) \\
\% / M(\mathrm{SD})\end{array}$ & $\begin{array}{c}\text { France }(n=200) \\
\% / M(\mathrm{SD})\end{array}$ & $\begin{array}{c}\text { Spain }(n=200) \\
\% / M(\mathrm{SD})\end{array}$ & $\begin{array}{c}\text { Italy }(n=203) \\
\% / M(\mathrm{SD})\end{array}$ & Significance \\
\hline Sex (\% men) & $71 \%$ & $53 \%$ & $85 \%$ & $78 \%$ & $* * *$ \\
\hline Age & $41.2(0.5)$ & $45.0(0.9)$ & $36.7(0.8)$ & $39.3(0.5)$ & $* * *$ \\
\hline \multicolumn{6}{|l|}{ Education } \\
\hline Primary $(<)$ & $54 \%$ & $44 \%$ & $78 \%$ & $50 \%$ & $* * *$ \\
\hline Secondary & $27 \%$ & $23 \%$ & $20 \%$ & $37 \%$ & $* * *$ \\
\hline Tertiary & $19 \%$ & $33 \%$ & $2 \%$ & $13 \%$ & $* * *$ \\
\hline \multicolumn{6}{|c|}{ Residence permit } \\
\hline $\mathrm{RP}$ & $80 \%$ & $90 \%$ & $64 \%$ & $79 \%$ & $* * *$ \\
\hline Visa & $4 \%$ & $2 \%$ & $8 \%$ & $4 \%$ & $* * *$ \\
\hline No RP & $16 \%$ & $8 \%$ & $28 \%$ & $17 \%$ & $* * *$ \\
\hline
\end{tabular}

Notes: Weighted percentages are shown.

All current migrants are included in this Table.

${ }^{a}$ Percentages are reported for categorical variables; means and standard deviations are reported for continuous variables (i.e., age).

${ }^{\mathrm{b}}$ Residence permit: $\mathrm{RP}=$ migrant has a residence permit or does not require one due to citizenship acquisition;

Visa $=$ migrant has a visa; No RP $=$ migrant does not have a permit (i.e., undocumented migrant).

$* p<0.10, * * p<0.05, * * * p<0.01$.

Source: MAFE-Ghana; MAFE-Congo; MAFE-Senegal - Biographic surveys. 
have had to establish themselves in the new country. In the Senegalese case, this longer history has also allowed for the gender ratio to become somewhat more even. This change in the gender ratio is not the case for the other two flows, which were more balanced genderwise to begin with. Furthermore, migrants who move to the former colonial country also tend to be more highly educated. This trend reflects the fact that the educational systems in the African countries are based on those of the former colony and are conducted in the same language. Thus, either more educated migrants are attracted because they can more easily exercise their professions there or migrants can reach higher levels of schooling because of the relative ease of integrating within a schooling system that is similar to their own in structure and language.

\section{Transnational Family Typology}

Before turning to the analysis of characteristics of transnational families, we take a closer look at the different forms that migrant families take. We distinguish between four types of migrant family forms: "no children or spouses," who have not yet started a family; "always unified," who have always been together, either because they were formed abroad and still live together or because they all migrated together; "reunified," who at a former time had been transnational for at least 1 year and are now reunified; and "transnational" who are currently living separately from a spouse in a different country and/or at least having one child under the age of 18 . These categories recall those used in Hondagneu-Sotelo's (1994) study of "independent," "family unit," and "family stage" migration, respectively, where we additionally make the distinction within family unit migration indicating whether families were always together or came together after reunification. Furthermore, our categorization of "transnational families" explicitly makes no assumption about whether families will ultimately reunify or where they will reunify, whereas Hondagneu-Sotelo's categories are defined with the implicit assumption that ultimately family members will reunify in the destination country. In Tables 4 and 5, we look separately at the living arrangements between parents and their children and between spouses.

The striking finding in the two tables is that although family reunification is considered to be one of the main channels for migrants to enter Europe and has therefore gotten much policy attention (Kraler, 2010), the actual arrangements in which migrants live show that (1) many 
TABLE 4

Living Arrangements Between Migrant Parents and Children

\begin{tabular}{|c|c|c|c|c|c|c|}
\hline \multirow[b]{2}{*}{ Living arrangements } & \multicolumn{2}{|c|}{ Ghanaian flow } & \multicolumn{2}{|c|}{ Congolese flow } & \multicolumn{2}{|c|}{ Senegalese flow } \\
\hline & $f$ & $\%$ & $f$ & $\%$ & $f$ & $\%$ \\
\hline No children $<18$ & 200 & 43.2 & 157 & 33.2 & 211 & 40.2 \\
\hline Always unified child (ren) & 123 & 39.3 & 140 & 36.1 & 146 & 21.0 \\
\hline Reunified child (ren) & 23 & 6.6 & 56 & 14.7 & 46 & 5.5 \\
\hline Transnational child (ren) & 64 & 10.9 & 73 & 16.0 & 200 & 33.3 \\
\hline Total & 410 & 100.0 & 426 & 100.0 & 603 & 100.0 \\
\hline
\end{tabular}

Notes: Unweighted frequencies and weighted percentages are shown.

Children above the age of 18 (and their whereabouts) are not considered, that is, no child also includes those with only children above the age of 18 ; In case of children under the age of 18 who are living at different locations, when at least 1 child under the age of 18 is not living with ego, it is considered "non-cohabiting".

Source: MAFE-Ghana; MAFE-Congo; MAFE-Senegal - Biographic surveys.

TABLE 5

Living Arrangements Between Migrant Couples

\begin{tabular}{|c|c|c|c|c|c|c|}
\hline \multirow[b]{2}{*}{ Living arrangements } & \multicolumn{2}{|c|}{ Ghanaian flow } & \multicolumn{2}{|c|}{ Congolese flow } & \multicolumn{2}{|c|}{ Senegalese flow } \\
\hline & $f$ & $\%$ & $f$ & $\%$ & $f$ & $\%$ \\
\hline No spouse & 187 & 45.7 & 206 & 50.6 & 186 & 33.5 \\
\hline Always unified spouses & 98 & 31.3 & 79 & 19.6 & 120 & 17.7 \\
\hline Reunified spouses & 66 & 14.8 & 80 & 17.6 & 121 & 13.1 \\
\hline Transnational spouses & 59 & 8.2 & 61 & 12.2 & 176 & 35.7 \\
\hline Total & 410 & 100.0 & 426 & 100.0 & 603 & 100.0 \\
\hline
\end{tabular}

Notes: Unweighted frequencies and weighted percentages are shown.

Informal unions are not considered, that is, spouse always refers to marriage, and conversely, no spouse also includes those within an informal union.Source: MAFE-Ghana; MAFE-Congo; MAFE-Senegal - Biographic surveys.

migrants do not qualify for reunification because they do not have a spouse and/or children and (2) families live transnationally more often than they live reunified. First, Tables 4 and 5 show that a considerable number of migrants do not have any children, ranging from 33 percent among Congolese 13 percent among Ghanaians, and do not have a spouse, ranging fre 4 percent of Senegalese to 51 percent of Congolese. These are migrants who, by definition, do not qualify for family reunification, and they make up a substantial proportion of migrants from the three countries. Second, in all three flows, the least common family form is being reunified, except in the case of Congolese spouses, for whom being reunified is second to being always unified.

Table 6 combines the analyses above to examine all members of the nuclear family and shows that transnational family life is common for all migration flows and across the different European destination countries. Yet clear differences emerge when comparing the three flows, as well as among the receiving countries. Senegalese migrants are more likely to live 
in a transnational family formation in Europe (44\%), followed by Congolese $(23 \%)$ and Ghanaians (17\%). Within these migration flows, the receiving context seems to be relevant. Large differences exist for Senegalese migrants, who commonly live in transnational families in Italy $(66 \%)$ and in Spain (56\%), whereas such formations are much less common for them in France (23\%). For Congolese and Ghanaians living in the UK, transnational family life is less common $\%$ and $13 \%$, respectively) than for those living in Belgium (30\%) and the Netherlands (34\%). Finally, considering that reunified families were also at one time in the past transnational families for at least 1 year or more, transnational family formations, past and present, are prevalent in all three migration flows ranging from 57 percent for Senegalese to 34 percent for Ghanaians.

TABLE 6

Distribution of the Family Arrangements Typology, by Migration Flow and Survey Country, Spouses and ChILdREN Combined

\begin{tabular}{|c|c|c|c|c|c|c|}
\hline \multirow[b]{3}{*}{ Family arrangement typology } & \multicolumn{6}{|c|}{ Ghanaian flow } \\
\hline & \multicolumn{2}{|c|}{ All countries } & \multicolumn{2}{|c|}{ the Netherlands } & \multicolumn{2}{|c|}{ UK } \\
\hline & $f$ & $\%$ & $f$ & $\%$ & $f$ & $\%$ \\
\hline No nuclear family & 121 & 26.5 & 74 & 22.5 & 47 & 27.1 \\
\hline Always unified family & 119 & 39.7 & 62 & 24.4 & 57 & 42.2 \\
\hline Reunified family & 69 & 17.3 & 46 & 19.0 & 23 & 16.9 \\
\hline Transnational family & 101 & 16.5 & 81 & 34.1 & 20 & 13.8 \\
\hline \multirow[t]{3}{*}{ Total } & 410 & 100.0 & 263 & 100.0 & 147 & 100.0 \\
\hline & \multicolumn{6}{|c|}{ Congolese flow } \\
\hline & \multicolumn{2}{|c|}{ All countries } & \multicolumn{2}{|c|}{ Belgium } & \multicolumn{2}{|c|}{ UK } \\
\hline Family arrangement typology & $\bar{f}$ & $\%$ & $f$ & $\%$ & $f$ & $\%$ \\
\hline No nuclear family & 114 & 26.0 & 80 & 26.7 & 34 & 25.1 \\
\hline Always unified family & 106 & 27.3 & 59 & 22.4 & 47 & 33.4 \\
\hline Reunified family & 102 & 23.9 & 56 & 20.5 & 46 & 28.3 \\
\hline Transnational family & 104 & 22.8 & 83 & 30.4 & 21 & 13.2 \\
\hline Total & 426 & 100.0 & 278 & 100.0 & 148 & 100.0 \\
\hline
\end{tabular}

Senegalese flow

\begin{tabular}{|c|c|c|c|c|c|c|c|c|}
\hline \multirow[b]{3}{*}{ Family arrangement typology } & \multirow{2}{*}{\multicolumn{2}{|c|}{ All countries }} & \multirow{2}{*}{\multicolumn{2}{|c|}{ France }} & \multirow{2}{*}{\multicolumn{2}{|c|}{ Spain }} & \multirow{2}{*}{\multicolumn{2}{|c|}{ Italy }} \\
\hline & & & & & & & & \\
\hline & $f$ & $\%$ & $f$ & $\%$ & $f$ & $\%$ & $f$ & $\%$ \\
\hline No nuclear family & 127 & 24.3 & 54 & 26.3 & 33 & 26.8 & 40 & 19.5 \\
\hline Always unified family & 118 & 18.6 & 65 & 31.8 & 34 & 8.1 & 19 & 7.7 \\
\hline Reunified family & 111 & 12.9 & 34 & 18.7 & 46 & 9.6 & 31 & 6.9 \\
\hline Transnational family & 247 & 44.2 & 47 & 23.2 & 87 & 55.5 & 113 & 65.9 \\
\hline Total & 603 & 100.0 & 200 & 100.0 & 200 & 100.0 & 203 & 100.0 \\
\hline
\end{tabular}

Note: Unweighted frequencies and weighted percentages are shown.

Source: MAFE-Ghana; MAFE-Congo; MAFE-Senegal - Biographic surveys 


\section{Characteristics of Transnational Family Arrangements}

Logistic regression analysis was used to determine which characteristics are associated with transnational family life. Migrants without nuclear family members are excluded. Tables 7-9 present the results for the three African flows separately.

Table 7 shows that, for the pooled sample, including all Ghanaians, irrespective of their country of destination (Model 1), age and occupational status are significantly associated with being in a transnational family. These differences disappear when controlling for migration-related

TABLE 7

Logistic Estimation of Being in a Transnational Family - Ghanaian Migrant Flow (Odds Ratios SHOWN)

\begin{tabular}{|c|c|c|c|c|c|c|}
\hline \multirow[b]{2}{*}{ Variables } & \multicolumn{2}{|c|}{ Pooled sample } & \multicolumn{2}{|c|}{ the Netherlands } & \multicolumn{2}{|c|}{$\mathrm{UK}$} \\
\hline & Model (1) & Model (2) & Model (3) & Model (4) & Model (5) & Model (6) \\
\hline \multirow[t]{2}{*}{ Female } & 0.75 & 0.72 & 0.74 & 0.77 & 0.9 & 0.73 \\
\hline & $(0.22)$ & $(0.25)$ & $(0.26)$ & $(0.33)$ & $(0.54)$ & $(0.63)$ \\
\hline \multirow[t]{2}{*}{ Age } & $0.96^{* * *}$ & 1.02 & $0.96^{* *}$ & 1.01 & 0.96 & 1.12 \\
\hline & $(0.02)$ & $(0.02)$ & $(0.02)$ & $(0.03)$ & $(0.03)$ & $(0.1)$ \\
\hline \multirow[t]{2}{*}{ Education } & 1.01 & 1.03 & 1.04 & $1.08^{*}$ & 0.93 & $0.87^{*}$ \\
\hline & $(0.04)$ & $(0.05)$ & $(0.05)$ & $(0.06)$ & $(0.08)$ & $(0.09)$ \\
\hline \multirow[t]{2}{*}{ Occupational status } & $0.97^{* * *}$ & 0.99 & $0.97^{* * *}$ & 0.99 & 0.98 & 0.96 \\
\hline & $(0.01)$ & $(0.01)$ & $(0.01)$ & $(0.02)$ & $(0.02)$ & $(0.03)$ \\
\hline \multicolumn{7}{|c|}{ Subjective wealth status } \\
\hline \multicolumn{7}{|c|}{ Absolutely (ref.) } \\
\hline \multirow[t]{2}{*}{ It depended } & 0.78 & 0.85 & 0.7 & 0.85 & 1.22 & 0.78 \\
\hline & $(0.3)$ & $(0.38)$ & $(0.34)$ & $(0.48)$ & $(0.81)$ & $(0.72)$ \\
\hline \multirow[t]{2}{*}{ Not at all } & 1.24 & 1 & 2.19 & 0.69 & 0.71 & 1.19 \\
\hline & $(0.83)$ & $(0.85)$ & $(2.08)$ & $(0.82)$ & $(0.87)$ & $(1.77)$ \\
\hline \multirow{2}{*}{ Period of arrival } & & $1.16^{* * *}$ & & $1.13^{* * *}$ & & $1.62^{* * *}$ \\
\hline & & $(0.04)$ & & $(0.04)$ & & $(0.28)$ \\
\hline \multicolumn{7}{|l|}{ Residence permit (RP) } \\
\hline \multicolumn{7}{|l|}{ RP (ref.) } \\
\hline \multirow[t]{2}{*}{ Visa } & & 0.88 & & 0.36 & & 1.98 \\
\hline & & $(0.49)$ & & $(0.32)$ & & $(1.96)$ \\
\hline \multirow[t]{2}{*}{ No RP } & & $3.97^{* * *}$ & & $6.73^{* * *}$ & & 0.17 \\
\hline & & $(2.17)$ & & $(4.36)$ & & $(0.28)$ \\
\hline \multicolumn{7}{|l|}{ Country } \\
\hline \multicolumn{7}{|l|}{ UK (ref.) } \\
\hline \multirow[t]{2}{*}{ the Netherlands } & & $2.18^{* *}$ & & & & \\
\hline & & $(0.94)$ & & & & \\
\hline \multirow[t]{2}{*}{ Constant } & $8.29^{* * *}$ & $0.00^{* * *}$ & $5.19^{*}$ & $0.00^{* * *}$ & 12.03 & $0.00^{* * *}$ \\
\hline & $(8.14)$ & 0 & $(6.17)$ & 0 & $(23.47)$ & $(0)$ \\
\hline Observations & 228 & 223 & 154 & 153 & 74 & 70 \\
\hline Log likelihood & -140.3 & -112.4 & -100.4 & -81.95 & -37.39 & -21.5 \\
\hline$d f$ & 6 & 10 & 6 & 9 & 6 & 9 \\
\hline$\chi^{2}$ & 16.05 & 65.12 & 8.348 & 44.1 & 4.988 & 29.74 \\
\hline
\end{tabular}

Note: Standard errors in parentheses; ${ }^{*} p<0.10, * * p<0.05, * * * p<0.01$.

Source: MAFE-Ghana - Biographic surveys. 
TABLE 8

Logistic Estimation of Being in a Transnational Family - Congolese Migrant Flow (Odds Ratios SHOWN)

\begin{tabular}{|c|c|c|c|c|c|c|}
\hline \multirow[b]{2}{*}{ Variables } & \multicolumn{2}{|c|}{ Pooled sample } & \multicolumn{2}{|c|}{ Belgium } & \multicolumn{2}{|c|}{ UK } \\
\hline & Model (1) & Model (2) & Model (3) & Model (4) & Model (5) & Model (6) \\
\hline Female & $\begin{array}{l}0.9 \\
(0.35)\end{array}$ & $\begin{array}{l}1.29 \\
(0.63)\end{array}$ & $\begin{array}{c}0.62 \\
(0.3)\end{array}$ & $\begin{array}{l}1.04 \\
(0.6)\end{array}$ & $\begin{array}{c}0.57 \\
(0.54)\end{array}$ & $\begin{array}{c}0.72 \\
(0.98)\end{array}$ \\
\hline Age & $\begin{array}{l}0.96^{*} \\
(0.02)\end{array}$ & $\begin{array}{l}1.06^{* *} \\
(0.03)\end{array}$ & $\begin{array}{l}0.96^{*} \\
(0.03)\end{array}$ & $\begin{array}{l}1.04 \\
(0.04)\end{array}$ & $\begin{array}{c}0.99 \\
(0.06)\end{array}$ & $\begin{array}{l}1.13^{*} \\
(0.09)\end{array}$ \\
\hline Education & $\begin{array}{l}1.01 \\
(0.05)\end{array}$ & $\begin{array}{l}0.97 \\
(0.06)\end{array}$ & $\begin{array}{l}0.81^{* * *} \\
(0.08)\end{array}$ & $\begin{array}{l}0.81^{* *} \\
(0.1)\end{array}$ & $\begin{array}{l}1.13 \\
(0.13)\end{array}$ & $\begin{array}{c}1.11 \\
(0.14)\end{array}$ \\
\hline Occupational status & $\begin{array}{l}0.99 \\
(0.01)\end{array}$ & $\begin{array}{l}1 \\
(0.01)\end{array}$ & $\begin{array}{l}1.01 \\
(0.02)\end{array}$ & $\begin{array}{l}1.01 \\
(0.02)\end{array}$ & $\begin{array}{c}0.96 \\
(0.03)\end{array}$ & $\begin{array}{l}0.92^{* *} \\
(0.05)\end{array}$ \\
\hline \multicolumn{7}{|c|}{$\begin{array}{l}\text { Subjective wealth status } \\
\text { Absolutely (ref.) }\end{array}$} \\
\hline It depended & $\begin{array}{l}0.95 \\
(0.58)\end{array}$ & $\begin{array}{l}1.81 \\
(1.32)\end{array}$ & $\begin{array}{l}1.51 \\
(1.43)\end{array}$ & $\begin{array}{l}1.49 \\
(1.56)\end{array}$ & $\begin{array}{l}1.5 \\
(1.41)\end{array}$ & $\begin{array}{l}5.39 \\
(8.01)\end{array}$ \\
\hline Not at all & $\begin{array}{c}1 \\
(0)\end{array}$ & $\begin{array}{l}1 \\
(0)\end{array}$ & $\begin{array}{l}1 \\
(0)\end{array}$ & $\begin{array}{l}1 \\
(0)\end{array}$ & $\begin{array}{l}1 \\
(0)\end{array}$ & $\begin{array}{l}1 \\
(0)\end{array}$ \\
\hline Period of arrival & & $\begin{array}{l}1.21^{* * *} \\
(0.05)\end{array}$ & & $\begin{array}{l}1.19^{* * *} \\
(0.06)\end{array}$ & & $\begin{array}{l}1.51^{* * *} \\
(0.23)\end{array}$ \\
\hline \multicolumn{7}{|c|}{$\begin{array}{l}\text { Residence permit (RP) } \\
\text { RP (ref.) }\end{array}$} \\
\hline Visa & & $\begin{array}{l}0.13^{* *} \\
(0.14)\end{array}$ & & $\begin{array}{c}1 \\
(0)\end{array}$ & & $\begin{array}{l}4.13 \\
(7.65)\end{array}$ \\
\hline No RP & & $\begin{array}{l}4.84^{*} \\
(4.75)\end{array}$ & & $\begin{array}{c}1 \\
(0)\end{array}$ & & $\begin{array}{c}0.77 \\
(1.34)\end{array}$ \\
\hline \multicolumn{7}{|l|}{ Country } \\
\hline Belgium & & $\begin{array}{l}3.70^{* * *} \\
(2.02)\end{array}$ & & & & \\
\hline Constant & $\begin{array}{c}1.93 \\
(2.19)\end{array}$ & $\begin{array}{l}0.00^{* * *} \\
(0)\end{array}$ & $\begin{array}{l}109.35^{* * *} \\
(220.83)\end{array}$ & $\begin{array}{l}0.00^{* * *} \\
(0)\end{array}$ & $\begin{array}{c}0.18 \\
(0.45)\end{array}$ & $\begin{array}{l}0.00^{* * *} \\
(0)\end{array}$ \\
\hline Observations & 163 & 159 & 109 & 96 & 54 & 53 \\
\hline Log likelihood & -91.34 & -69.89 & -63.27 & -47.31 & -21.48 & -14.65 \\
\hline$d f$ & 5 & 9 & 5 & 6 & 5 & 8 \\
\hline$\chi^{2}$ & 3.332 & 37.38 & 8.752 & 21.27 & 2.341 & 15.67 \\
\hline
\end{tabular}

Note: Standard errors in parentheses; $*_{p}<0.10, * * p<0.05, * * * p<0.01$.

Source: MAFE-Congo - Biographic surveys.

characteristics (Model 2). Instead, being in a transnational family is associated with later arrival at destination, being undocumented, and being in the Netherlands. Models 3 and 4 show the same pattern for Ghanaian migrants in the Netherlands. Again, migrants in a transnational family have arrived later and are more likely to be undocumented (Model 4). They also have slightly higher education than migrants who are not in transnational families. For Ghanaians in the UK (Models 5 and 6), a reversed relationship with education is found. In the UK, being in a transnational family is associated with having less education. The relationship 


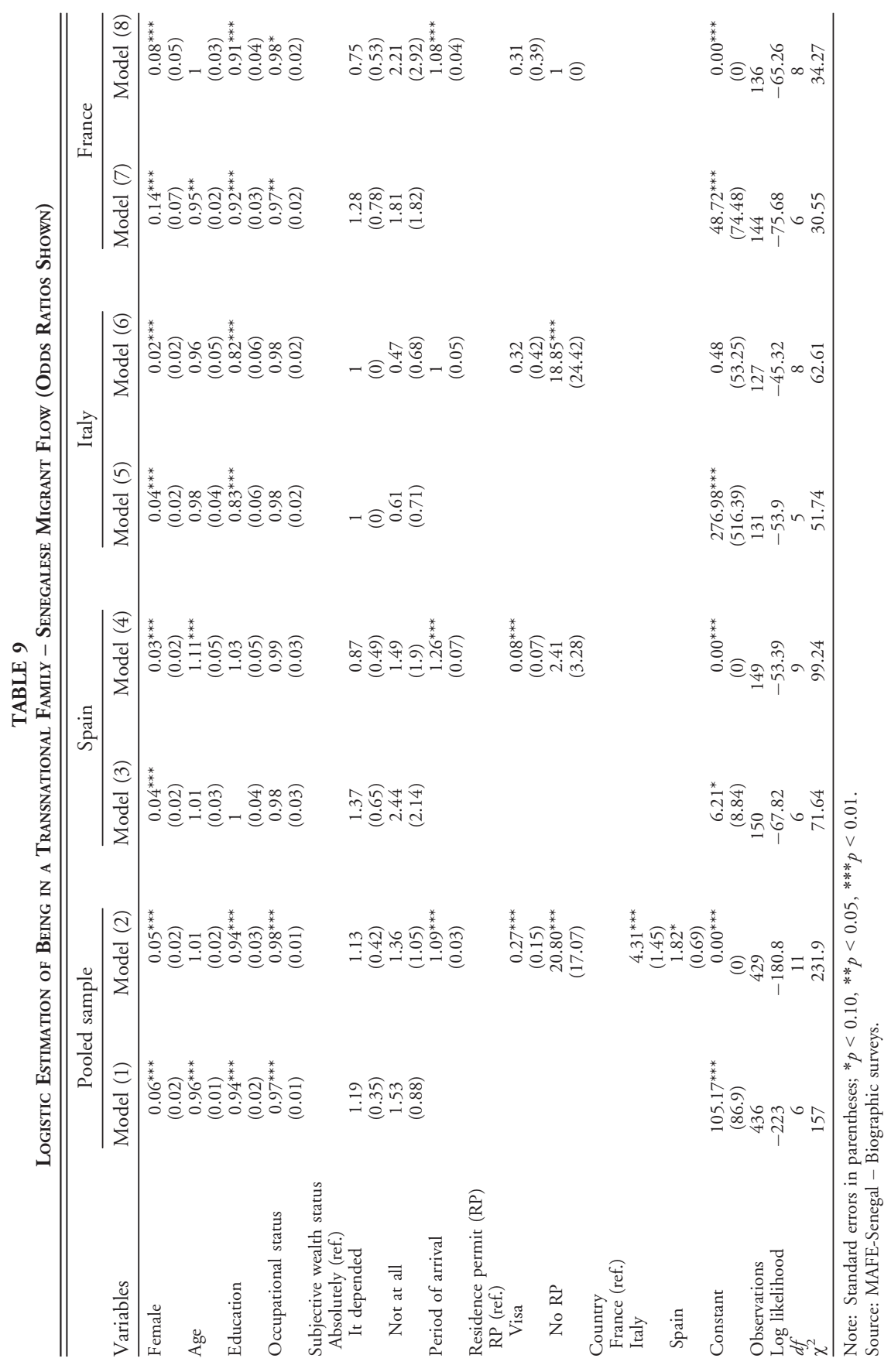


with undocumented status is also not significant for Ghanaian migrants in the UK (Model 6). However, this lack of significance is most likely due to the small sample size, as the UK sample contained few undocumented migrants. As in the Netherlands, being in a transnational family is related to later arrival in the UK.

Similar to results for Ghanaian migrants, transnational family life for Congolese migrants (Table 8) is related to later arrival in the country of destination for the pooled sample (Model 2) and for the separate samples in Belgium and the UK (Models 4 and 6). Model 2 indicates that transnational family life is more likely for Congolese migrants in Belgium than in the UK. Congolese migrants in a transnational family are also older (Model 2), but this holds only for migrants in the UK (Model 6). In Belgium, Congolese migrants in transnational families are more likely to be less educated (Model 4). No relationship with education was found in the UK, but lower occupational status is significantly related to being in a transnational family (Model 6).

Also for Congolese migrants, there is a strong relationship between transnational family life and undocumented status (Model 2). However, looking at the two samples (Belgium and the DR Congo) separately, it is not possible to estimate whether undocumented status affects the odds of being in a transnational family in Belgium due to the small number of undocumented migrants in the Belgian sample. In the UK, no significant relationship was found between undocumented status and transnational family life. Finally, there are fewer Congolese transnational families in the UK than in Belgium, similar to the patterns found for Ghanaian migrants.

For Senegalese migrants (Table 9), most socioeconomic and migration-related characteristics are associated with being in a transnational family (Models 1 and 2): Migrants with a low level of education and a low socioeconomic status are more likely to be in a transnational family, as are undocumented migrants and those who arrived more recently. Contrary to the Congolese and Ghanaian migrants, gender plays an important role in shaping transnational family life for Senegalese migrants, as men are much more likely to be in a transnational family than women. Senegalese migrants in Spain and Italy are more likely to be in a transnational family than migrants in France (Model 2).

Models 3 through 8 show that the main differences between destination countries for Senegalese migrants relate to the role of education and occupational status. In Italy and France, transnational family life is related 
to less education, but not in Spain. In France, lower occupational status is significantly related to transnational family life. In Spain and France, migrants in a transnational family have, on average, arrived more recently. All Senegalese migrants in Italy, irrespective of family status, arrived recently; therefore, it was not possible to estimate the effect of the period of arrival. In Italy, undocumented status is strongly correlated with transnational family life. In France, we could not estimate the relationship of family life to undocumented status due to the fact that all migrants with families, whether transnational or not, are documented.

\section{DISCUSSION AND CONCLUSIONS}

Results show that transnational family life is common for all migration flows and across the different European destination countries. Yet clear differences emerge when comparing the three flows, as well as among the receiving countries. Placing these finding in context offers some potential explanations for the differences that have been found between migrant flows and, within the same flow, between destination countries.

\section{Family Norms}

Differences in family organization and gender norms in the country of origin help explain why transnational family arrangements are more prevalent among Senegalese migrants and also why gender is only significantly associated with living transnationally in the Senegalese case. In Senegal, multilocal residence, irrespective of spousal migration, is common, and more so than in Ghana and the DR Congo (Marie, 1997; Locoh and Mouvagha-Sow, 2005; Riccio, 2008). Additionally, even though qualitative evidence shows the existence of independent migration among Senegalese women, especially among merchants (Blanchard, 2007), strong gender norms generally place women under the protection and surveillance of the husband's family (Bruggenhagen, 2004), and statistical evidence shows that autonomous female migration is not on the rise among Senegalese women (Toma, 2012). Migration is still a predominantly male activity. If women migrate, family reunification is usually the motive, hence the low likelihood for female migrants to be in transnational families. In contrast, women in Ghana, for example, have been historically engaged in commerce and trade networks within the West African region and customarily have a high degree of individual autonomy, including 
having their own financial resources and budgets within the family (Clark, 1999).

More generally, the fact that transnational family formations are prevalent in all three groups may in part be a reflection of family norms in the three countries in which child fosterage and social parenthood are prevalent, and where multilocal residence of spouses is common. That is, living transnationally may, in part, be the result of a choice for families. For example, Riccio (2008:222) describes a "resistance to family reunification" among Senegalese migrants in Italy and interprets it as a product both of an economic choice (relatives are more expensive to maintain in Europe) and of a social option. Likewise, Bledsoe and Sow (2011) argue that for some Ghanaian parents, having their children be raised in high-quality boarding schools in Ghana is their preferred option. Finally, Poeze and Mazzucato (2014) show how children living in Ghana with migrant parents abroad can view their caregivers in Ghana as "second" mothers.

\section{Migration History and Origin Country Contexts}

The migration history between particular countries is also influential in the types of families found in the receiving countries. Senegalese migrants appear to be in transnational families more often in Spain and Italy than in France, where more families were formed and reunified. The longer history of migration between France and Senegal, related to colonial ties, has allowed time for more migrants to establish themselves there and to obtain residence permits, or even French nationality, allowing for family reunification or increasing the likelihood of family formation at destination. Migration to Spain and Italy is a relatively newer phenomenon for Senegalese migrants (Sakho et al., 2013), giving them less time to reunify or form new families.

While migration history seems to explain the results for Senegalese migrants, origin country context is more important in explaining the case of Congolese migration. Belgium and the DR Congo have a long history of migration, reflecting past colonial ties (as was the case for Senegal and France), but this history did not result in more established or reunified families in Belgium compared to the UK. Instead, a reverse pattern was found, with more transnational families in Belgium (30\%) than in the UK (13\%). To understand this, we need to look at how different motivations for migration, which are intricately linked to conditions in the home country, combine with receiving country policies, resulting in migrants 
from the same African flow having different family formations in different receiving countries. Congolese migrants in Belgium have more varied motivations, with people migrating for work, family, and study, while Congolese migrants in the UK mostly entered the country as asylum seekers. This reflects the explicit target of UK policy of granting asylum status to Congolese refugees in the late 1990s. These different modes of entry have consequences for the types of family formations among migrants because refugees receive relatively more support in their family reunification process than do economic migrants, who must meet more requirements. This fact helps to explain why Congolese migrants are less likely to live in transnational family formations in the UK than in Belgium.

\section{Receiving Country's Socioeconomic Contexts and Policies}

As African migration patterns to Europe increasingly diversify from historical colonial ties (Grillo and Mazzucato, 2008), different European contexts become more important in attracting different types of migrants from the same country of origin. European receiving countries differ in terms of policies as well as economic opportunities, schooling system, and language, among other conditions. These differences help to explain why different types of family formations prevail within the same flows in different receiving countries. For instance, Ghanaians are less likely to be in transnational family formations in the UK than in the Netherlands because the Netherlands was more restrictive than the UK in the requirements it imposed for family reunification during the 1990s (Kofman et al., 2008; Mazzucato, 2008). In addition, the fact that both Congolese and Ghanaians in the UK have low rates of transnational family formations in comparison with their counterparts in Belgium and the Netherlands further attests to the relatively admissive UK family reunification policies in the 1990s.

Another example in which receiving country context helps to explain differences in family formations relates to language and educational systems, as exemplified in the Ghanaian case where transnational families are more prevalent in the Netherlands than in the UK. The UK is a preferable place for parents to bring their children compared to the Netherlands due to the lack of a language barrier and the commonalities in the schooling system. In a qualitative study among Ghanaian migrant parents in the Netherlands, researchers found that some parents prefer for their children to remain in Ghana to avoid difficulties in school related to the Dutch language (Poeze and Mazzucato, 2012). 
Other destination country contexts are of importance, such as the types of jobs that migrants can access, determining their occupational status. Lower occupational status is found to be associated with transnational families as lower paid and often insecure jobs impede migrants from qualifying for reunification and affect the choices they make for where to best raise their children (Parreñas 2005; Silvey 2004). Importantly, receiving country migration policies are also related to transnational family formations to the extent that they determine migrants' status in the receiving country. Our analyses show that, in all cases where there were undocumented migrants in the sample, undocumented status was, across the board, significantly associated with living in transnational family formations.

In this article, we have expressly used a restricted definition of family, limiting the analysis to nuclear family members, as these are the members who are eligible for family reunification in European countries. These estimates are thus conservative relative to taking other members of the extended family into consideration. It could be argued that transnational families at the time of the survey will become reunified families in the future. However, longitudinal analyses on reunification show that living apart together is often a long-lasting situation for African families (Beauchemin et al., 2014). In the end, transnational families are found to be common and exist to varying degrees among different African populations in Europe. This prevalence highlights the importance of studying the various forms that families take without assuming that all nuclear family members will be located in the same nation-state (Mazzucato and Schans, 2011) or that they will eventually reunify. Such research is important as migratory flows between the global South and North increasingly entail the dispersal of nuclear family members over the globe. Despite distances, family ties persist, and family responsibilities and care are organized transnationally.

This article presents a descriptive and comparative analysis of the forms of families who migrate between Africa and Europe; it is so far the only quantitative study, to our knowledge, that includes cross-country comparisons and focuses on African European migration flows. By comparing both countries of origin and countries of destination, differences in family arrangements and migration patterns among Ghana, Senegal, and the DR Congo were explored, as well as differences within these groups based on the European destination countries.

When taken together, the findings suggest that, given the choice, some migrants prefer to live transnationally, especially when this family 
arrangement continues a pre-established pattern guided by family norms in the sending country. This pattern explains, in part, the case of Senegalese migrants. Furthermore, a conscious choice may be made in favor of a transnational family formation due to migrants' assessment of what is best for their children, comparing educational systems and language in the sending and receiving countries (Bledsoe and Sow, 2011), as was, in part, the case for Ghanaian migrants. At the same time, however, other migrants, when given the choice, prefer to reunite with their families at destination. In these cases, family reunification laws and migration policies are most strongly associated with living in transnational family formations. In such cases, transnational family life is not a choice but a condition imposed on migrants by European countries' family reunification and migration policies.

This quantitative study helps to assess the prevalence of transnational families and the factors associated with such family formations, thereby adding to findings from small scale in-depth case studies on the lived experiences of migrants. Further qualitative research should investigate how exactly the associated factors found in this study interact with decision making on whether to live transnationally or to reunify and whether and how preferences of individual family members regarding reunification are shaped by state policies. Finally, more qualitative and quantitative analyses are warranted on the effects on different family members of transnational family life versus living reunified (both documented and undocumented) in the destination country.

\section{REFERENCES}

Åkesson, L., J. Carling, and H. Drotbohm

2012 "Mobility, Moralities and Motherhood: Navigating the Contingencies of Cape Verdean Lives." Journal of Ethnic and Migration Studies 38(2):237-260.

Basch, L., N. Glick-Schiller, and C. Szanton-Blanc

1994 Nations Unbound: Transnational Projects, Postcolonial Predicaments and Deterritorialized Nation-States. Amsterdam: Gordon and Breach.

Beauchemin, C.

2012 Migrations Between Africa and Europe: Rationale for a Survey Design. Methodological Note No. 5. Paris: INED.

2014 "Reunifying vs. Living Apart Together Across Borders: A Double Comparative Analysis of African Migration." International Migration Review (this issue).

— K. Kaarls, and V. Mazzucato

2013 Senegalese Migrants Between Here and There: An Overview of Family Patterns. MAFE Working Paper No. 33. Paris: INED. 
Bernhard, J. K., P. Landolt, and L. Goldring

2005 Transnational, Multi-Local Motherhood: Experiences of Separation and Reunification among Latin American Families in Canada, CERIS Working Paper No. 40. York: York University, Latin America research Group.

2009 "Transnationalizing Families: Canadian Immigration Policy and the Spatial Fragmentation of Care-giving among Latin American Newcomers." International Migration 47(2):3-31. doi:10.1111/j.1468-2435.2008.00479.x.

Blanchard, M.

2007 "Migrantes sénégalaises "en solitaire" à Marseille. Des statuts ambigus entre marginalité et quête de reconnaissance." Diasporas. Histoire et sociétés (11):111-122.

Bhabha, J., and S. Shutter

1995 Women's Movements: Women under Immigration, Nationality and Refugee Law. Stoke-on-Trent: Trentham Books.

Bledsoe, C.

1990 “No Success Without Struggle': Social Mobility and Hardship for Foster Children in Sierra Leone." Man 25(1):70-88.

2011 "Back to Africa: Second Chances for the Children of West African Immigrants." Journal of Marriage and Family 73(4):747-762. doi:10.1111/j.1741-3737.2011. 00843.x.

Bruggenhagen, $\mathrm{B}$.

2004 "Domestic Object(ion)s: The Senegalese Murid Trade Diaspora and the Politics of Marriage Payments, Love, and State Privatization." In Producing African Futures: Ritual and Reproduction in a Neoliberal Age. Ed. B. Weiss. Leiden: Brill. Pp. 21-53.

Bryceson, D. F., and U. Vuorela

2002 "Transnational Families in the Twenty-First Century." In The Transnational Family. New European Frontiers and Global Networks. Ed. D. F. Bryceson, and U. Vuorela. Oxford: Berg. Pp. 3-30.

Caarls, K. et al.

2013 Transnational Families Between Ghana, The Netherlands and the U.K. MAFE Working Paper No. 32. Paris: INED.

Clark, G.

1999 “Women's Practice of Kinship in Modern Ghana." Africa 69(01):66-86.

Coe, C.

2011 "What is the Impact of Transnational Migration on Family Life?" American EthnolDreby, J. ogist 38(1):148-163.

2006 "Honor and Virtue. Mexican Parenting in the Transnational Context." Gender and Society 20(1):32-59.

2007 "Children and Power in Mexican Transnational Families." Journal of Marriage and Family 69(4):1050-1064.

Faist, T.

2000 "Transnationalization in International Migration: Implications for the Study of Citizenship and Culture." Ethnic and Racial Studies 23(2):189-222.

Findley, S. A.

1997 "Migration and Family Interaction in Africa." In Family, Population and Development in Africa. Ed. A. Adepoju. London and New Jersey: Zed Books. Pp. 109-138. 
Foner, N.

1997 "What's New about Transnationalism? New York Immigrants Today and at the Turn of the Century." Diaspora: A Journal of Transnational Studies 6(3):355-375.

Fortes, M.

1950 "Kinship and Marriage among the Ashanti." In African Systems of Kinship and Marriage. Ed. A. R. Radcliffe-Brown, and D. Forde. New York: Oxford University Press. Pp. 252-284.

Fox, B., and M. Luxton

2001 "Conceptualizing Family." In Family Patterns, Gender Relations. Ed. B. Fox. Toronto: Oxford University Press. Pp. 22-33.

Ghana Statistical Service (GSS), Ghana Health Service (GHS), and ICF Macro

2009 Ghana Demographic and Health Survey 2008. Accra, Ghana: GSS, GHS, and ICF Macro.

Glick, J. E.

2010 "Connecting Complex Processes: A Decade of Research on Immigrant Families." Journal of Marriage and Family 72(3):498-515. doi:10.1111/j.1741-3737.2010. 00715.x.

Gonzalez Ferrer, A.

2011 "Spousal Reunification among Recent Immigrants in Spain: Links with Undocumented Migration and the Labour Market." In Gender, Generations and the Family in International Migration. Ed. A. Kraler, E. Kofman, M. Kohli, and C. Schmoll. Amsterdam: Amsterdam University Press. Pp. 193-218.

Goody, E. N.

1982 Parenthood and Social Reproduction. Fostering and Occupational Roles in West Africa. Cambridge: Cambridge University Press.

Grillo, R., and V. Mazzucato

2008 "Africa < > Europe: A Double Engagement." Journal of Ethnic and Migration Studies 34(2):175-198. doi:10.1080/13691830701823830.

Haagsman, K., and V. Mazzucato

2014 "The Quality of Parent-Child Relationships in Transnational Families: Angolan and Nigerian Migrant Parents in The Netherlands." Journal of Ethnic and Migration Studies 1-20. 40(11):1677-1696. doi:10.1080/1369183X.2013.871491.

Herrera-Lima, F.

2001 "Transnational Families: Institutions of Transnational Social Spaces." In New Transnational Social Spaces: International Migration and Transnational Companies in the Early 21st Century. Ed. L. Pries. New York: Routledge. Pp. 77-92.

Hondagneu-Sotelo, P.

1994 Gendered Transitions. Mexican Experiences of Immigration. Berkeley: University of California Press.

Hondagneu-Sotelo, P., and E. Avila

1997 “I'm Here, but I'm There'. The Meanings of Latina Transnational Motherhood.” Gender and Society 2(5):548-571.

King, R. et al.

2010 People on the Move. An Atlas of Migration. Berkeley: University of California Press.

Kofman, E., S. Lukes, V. Meetoo and P. Aaron

2008 Family Migration to United Kingdom: Trends, Statistics and Policies. NODE Policy Report. Vienna: BMWF/ICMPD.

König, R. S., and M. de Regt

2010 "Family Dynamics in Transnational African Migration to Europe: An Introduction." African and Black Diaspora: An International Journal 3(1):1-15. 
Koser, K., ed.

2003 New African Diasporas. London: Routledge.

Kraler, A.

2010 Civic Stratification, Gender and Family Migration Policies in Europe. NODE Final Report. Vienna: BMWF/ICMPD.

2013 "A Liberal Paradox: Expanding Rights, Reducing Access? Contemporary Patterns of Family Migration Policies in the EU." In Migration, Familie und Gesellschaft. Ed.

Locoh, T.

T. Geisen, T. Studer, and E. Yildiz. Wiesenbaden: VS Springer. 357-378.

1989 “Le Rôle des Familles et l'Accueil des Migrants dans les Villes Sfricaines." In L'Insertion Urbaine des Migrants en Afrique, Colloques et séminaires. Ed. S. Coulibaly, and P. Antoine. Paris: Orstom. Pp. 21-32.

- and M. Mouvagha-Sow

2005 "Vers de Nouveaux Modèles Familiaux en Afrique de l'Ouest." Paper presented at the XXV International Population Conference, Tours, France. July. Pp. 18-23.

Manuh, $\mathrm{T}$.

1999 "'This Place is not Ghana': Gender and Rights Discourse among Ghanaian Men and Women in Toronto." Ghana Studies 2(1999):77-95.

Marie, A.

1997 “Les Structures Familiales à l'Epreuve de l'Individualisation Citadine." In Ménages et Familles en Afrique: Approches des Dynamiques Contemporaines. Ed. M. Pilon. Paris: Centre Français sur la Population et le Développement. Pp. 279-299.

Mazzucato, V.

2008 "The Double Engagement: Transnationalism and Integration. Ghanaian Migrants' Lives Between Ghana and The Netherlands." Journal of Ethnic and Migration Studies 34(2):199-216.

- and D. Schans

2011 "Transnational Families and the Well-Being of Children: Conceptual and Methodological Challenges." Journal of Marriage and Family 73(4):704-712. doi:10.1111/j.17413737.2011.00840.x.

Ministère du Plan et Macro International

2008 Enquête Démographique et de Santé, République Démocratique du Congo 2007. Calverton, Maryland: Ministère du Plan et Macro International.

Ngondo, A. P.

1996 Nucléarisation du ménage biologique et renforcement du ménage social à Kinshasa.

Øien, C. Zaïre-Afrique (308):419-444.

2006 "Transnational Networks of Care: Angolan Children in Fosterage in Portugal." Ethnic and Racial Studies 29(6):1104-1117. doi:10.1080/01419870600960370.

Parreñas, R. S.

2005 Children of Global Migration: Transnational Families and Gendered Woes. Stanford: Stanford University Press.

Pascouau, Y., and H. Labayle

2011 "Conditions for Family Reunification Under Strain. A Comparative Study in Nine EU Member States." King Baudouin Foundation, European Policy Centre, Odysseus Network. <http://www.epc.eu/documents/uploads/pub_1369_conditionsforfami ly.pdf>. Accessed on May 2, 2013. 
Poeze, M., and V. Mazzucato

2014 "Transnational Fathering between Ghana and The Netherlands: Fathers' Perceptions, Obstacles and Opportunities." Paper presented at conference Rethinking Care: Anthropological Perspectives on Life Courses, Kin-Work and their TransLocal Entanglements, Berlin, Germany. December 6-8.

2013 "Ghanaian Children in Transnational Families: Understanding the Experiences of Left-Behind Children through Local Parenting Norms." In Transnational Families, Migration and the Circulation of Care. Ed. L. Baldassar, and L. Merla. London: Routledge. Pp. 149-169.

Portes, A., and R. Rumbaut

1990 Immigrant America: A Portrait. Berkeley: University of California Press.

Pribilsky, J.

2007 La Chulla Vida: Gender, Migration and the Family in Andean Ecuador and New York Riccio, B. City. Syracuse, NY: Syracuse University Press.

2008 "West African Transnationalisms Compared; Ghanaians and Senegalese in Italy." Journal of Ethnic and Migration Studies 34(2):217-234.

Sakho, P., C. Beauchemin, B. Schoumaker and M.-L. Flahaux

2013 New Patterns of Migration Between Senegal and Europe. MAFE Working Paper No. 21. Paris: INED.

Sassen, S.

2002 "Global Cities and Survival Circuits." In Global Woman: Nannies, Maids and Sex Workers in the New Economy. Ed. B. Ehrenreich, and A. Russell Hochschild. London: Granta Books. Pp. 254-274.

Schmalzbauer, L.

2004 "Searching for Wages and Mothering from Afar: The Case of Honduran Transnational Families." Journal of Marriage and Family 66(5):1317-1331. doi:10.2307/ 3600342.

Silvey, R.

2004 "Transnational domestication: state power and Indonesian migrant women in Saudi Arabia." Political Geography 23(3):245-264.

Schoumaker, B., and M.-L. Flahaux

2013 Changing Patterns Of Congolese Migration. MAFE Working Paper No. 19. Paris: INED.

- , and C. Mezger

2013 Sampling and Computation Weights in the MAFE Surveys. Methodological Note No. 6. Paris: INED.

Suarez-Orozco, C., I. L. G. Todorova, and J. Louie

2002 "Making up for Lost Time: The Experience of Separation and Reunification among Immigrant Families." Family Process 41(4):625-643.

Tiemoko, R.

2003 Migration, Return and Socio-Economic Change in West Africa: The Role of Family. Sussex Migration Working Paper 15. Sussex: Centre for Migration Research.

Toma, S.

2012 "Ties That Bind? Networks and Gender in International Migration: The Case of Senegal.” PhD Dissertation. University of Oxford. 
Van Walsum, S.

2009 "Transnational Mothering, National Immigration Policy, and European Law." In Migrations and Mobilities: Gender, Citizenship, Borders. Ed. S. Benhabib, and J. Resnik. New York: New York University Press. Pp. 228-250.

Wen, M., and D. Lin

2012 "Child Development in Rural China: Children Left Behind by Their Migrant Parents and Children of Nonmigrant Families." Child Development 83(1):120-136. doi:10.1111/j.1467-8624.2011.01698.x.

Wimmer, A., and N. Glick-Schiller

2002 "Methodological Nationalism and Beyond: Nation-State Building, Migration and the Social Sciences." Global Networks 2(4):301-334. doi:10.1111/1471-0374.00043. 